\title{
The influences of progenitor filtering, domestication selection and the boundaries of nature on the domestication of grain
} crops

\author{
Lucas A. Garibaldi, ${ }^{1,2}$ (D) | Marcelo A. Aizen ${ }^{3,4}$ (iD \\ Marina M. Strelin ${ }^{3}$ (D) | Lawrence D. Harder ${ }^{5}$
}

\author{
Agustín Sáez $^{3}$ (D) | Gabriela Gleiser ${ }^{3}$
}

${ }^{1}$ Universidad Nacional de Río Negro, Instituto de Investigaciones en Recursos Naturales, Agroecología y Desarrollo Rural, San Carlos de Bariloche, Río Negro, Argentina

${ }^{2}$ Consejo Nacional de Investigaciones Científicas y Técnicas, Instituto de Investigaciones en Recursos Naturales, Agroecología y Desarrollo Rural, San Carlos de Bariloche, Río Negro, Argentina

${ }^{3}$ Grupo de Ecología de la Polinización, Instituto de Investigaciones en Biodiversidad y Medioambiente (INIBIOMA), Universidad Nacional del Comahue - CONICET, San Carlos de Bariloche, Rio Negro, Argentina

${ }^{4}$ Wissenschaftskolleg zu Berlin, Berlin, Germany

${ }^{5}$ Department of Biological Sciences, University of Calgary, Calgary, AB, Canada

Correspondence

Lucas A. Garibaldi

Email: Igaribaldi@unrn.edu.ar

Funding information

Universidad Nacional del Comahue, Grant/ Award Number: B152/04; Fondo para la Investigación Científica y Tecnológica, Grant/Award Number: PICT 20131079 and PICT 2015-2333; Consejo Nacional de Investigaciones Científicas y Técnicas, Grant/Award Number: PIP 114-201101-00201; Natural Sciences and Engineering Research Council of Canada, Grant/Award Number: RGPIN/107375-2012

Handling Editor: Adam Martin

\begin{abstract}
1. Domestication generally involves two sequential processes: initial identification of wild species with desirable characteristics ('progenitor filtering') and subsequent artificial and natural selection that, respectively, improve features preferred by humans and adapt species to cultivation/captivity ('domestication selection'). Consequently, domesticated species can differ from wild species and may share characteristics owing to convergent evolution ('domestication syndrome'). Baring evolutionary constraints, domestication selection may generate extreme phenotypes that transcend the 'boundaries of nature' evident for wild species. Despite evidence of domestication syndromes in some clades, broader contributions of progenitor filtering and domestication selection to characteristics of contemporary domesticated species have received limited attention.
\end{abstract}

2. Using comparative analysis of 49 grain-crop and 87 wild annual plant species from 15 families, we (1) addressed whether plants of crop and wild species differ for mean seed number, per-seed mass and total seed-mass investment; (2) assessed contributions of (a) progenitor filtering and (b) domestication selection to these differences; (3) evaluated whether crop characteristics exceed the boundaries of nature and (4) assessed whether seed-production characteristics of grain crops constitute components of a generic domestication syndrome.

3. On average, grain-crop plants produce heavier seeds and greater total seed mass than wild species, but seed number per plant does not differ. Comparison of wild species between genera with or without crop species found no evidence of progenitor filtering. In contrast, crop species differed from congeneric wild species for the mass traits, but not for seed number. Greater seed investment by crops is consistent with artificial selection for enhanced seed yield (mass per harvested area), whereas heavier individual seeds suggest selection for improved nutritional quality and (or) adaptation to cultivation environments.

4. Seed number-size characteristics of grain-crop species lie within the bivariate variation among wild species and so do not exceed the boundaries of nature. Seed number and size varied similarly between species types and generally aligned with seed-investment isoclines, suggesting an upper investment limit. 
5. Despite greater average investment in seed production and individual seeds by grain-crop species, seed-production characteristics did not vary less among crop species than among wild species, which is inconsistent with a common domestication syndrome.

\section{KEYWORDS}

domestication, grain crops, life histories, plant breeding, seed investment, seed mass, seed number, trade-off

\section{1 | INTRODUCTION}

The seeds of a small number of annual grain-crop species have increasingly become key elements of human diets during the past 12,000 years (Harlan, 1992; Khoury et al., 2014). Characteristics of these species commonly differ from those of their wild relatives. In particular, individuals of grain crops often produce larger and (or) more seeds with limited dormancy that they retain longer before dispersal (Brown et al., 2009; Fuller, 2007; Meyer et al., 2012; Preece et al., 2017; Purugganan \& Fuller, 2009). These differences could reflect two goal-directed aspects of domestication (Abbo \& Gopher, 2017; Kluyver et al., 2017; Milla et al., 2015). The first involves 'progenitor filtering', whereby humans identify wild species with particularly desirable traits (e.g. high productivity, ease of harvest, rich nutritional quality, non-toxic) as targets for domestication (Cunniff et al., 2014; Milla et al., 2018; Preece et al., 2015). These species should be a non-random subset of all wild plant species for the relevant traits. Second, potential crops are subject to trait 'improvement' (Abbo \& Gopher, 2017; Kluyver et al., 2017; Milla et al., 2015 2018). Associated natural selection in response to agricultural environments and artificial selection imposed by farmers and plant breeders (collectively 'domestication selection'), and more recent genetic engineering have generated crop varieties that differ phenotypically and genetically from each other and their wild relatives (Abbo \& Gopher, 2017; Milla et al., 2015; Olsen \& Wendel, 2013; Purugganan \& Fuller, 2009). As domestication is expected to begin with distinctive species (progenitor filtering) and accentuate their distinctiveness (domestication selection), phenotypic comparison of related domesticated and wild species should expose the influences of these processes. This evidence might also usefully inform the design of breeding programs, especially intentional progenitor filtering, needed to meet the dietary demands of the growing, and increasingly affluent, human population (Roberts, 2011).

The domestication selection responsible for trait adaptation in crops differs from that experienced by wild individuals in two important ways. First, agricultural environments typically impose more intense intraspecific competition, but less intense interspecific competition, fewer pests, and greater nutrient, light and water availability (Anten \& Vermeulen, 2016; Harlan et al., 1973). Second, plant breeding and natural selection involve different performance measures: crops are selected to maximize collective annual reproductive output per harvested area (yield), rather than age-weighted genetic contributions to the next generation by individuals (fitness; Anten \& Vermeulen, 2016; Harlan et al., 1973). Together, the characteristic features of natural and artificial selection during crop domestication should favour altered resource allocation patterns and life histories (Milla et al., 2015, 2018). Indeed, owing to the uniqueness of both agricultural environments and the performance measures that accompany domestication, crop evolution may be able to transgress the 'boundaries of nature' that restrict feasible trait combinations for wild plants (Van Tassel et al., 2010).

Particularly relevant is the influence of trade-offs imposed by limited resource availability or investment that often constrain allocation options for individual plants (Lloyd, 1987, 1988). In the context of seed production, the relations of a plant's mean seed size $(S$; mass), its total seed number $(N)$ and its resource investment in seed production ( $I$; mass) govern these options. For an individual plant that fully expends its seed investment (i.e. $I=S \cdot N$ ), the physical conservation of matter imposes a strict trade-off on feasible combinations of seed number and mean seed size,

$$
N=\frac{I}{S}=I S^{-1}
$$

(Figure 1, grey lines: Lloyd, 1987; Smith \& Fretwell, 1974). This relation will also hold for a collection of plants that invest similarly in seed production but differ in the number-size combinations that they have implemented. If instead investment differs among individuals, populations or species, seed number and mean size need not vary strictly inversely among them (i.e. exponent $\neq-1$; e.g. Moles et al., 2004), even though each individual is necessarily subject to its own strict trade-off (van Noordwijk \& de Jong, 1986; Venable, 1992). Consistent deviations from an inverse relation among individuals (or species) identify particular associations of seed investment and its allocation among seeds. An exponent $>-1$ indicates that individuals with large seed investments produce proportionally larger seeds (Figure 1, gold line), whereas an exponent $<-1$ indicates that they produce proportionally more seeds (Figure 1, purple line). In such cases, the underlying inverse relation associated with within-individual trade-offs will be evident only after accounting for variation in total seed investment (e.g. Aarssen \& Jordan, 2001; Henery \& Westoby, 2001).

The characteristics of natural and artificial selection suggest different expectations for the evolution of seed investment and number-size relations. Natural selection of the optimal number-size combination $\left(N^{*}=S^{*-1}\right)$ given seed investment per plant $I$ balances 


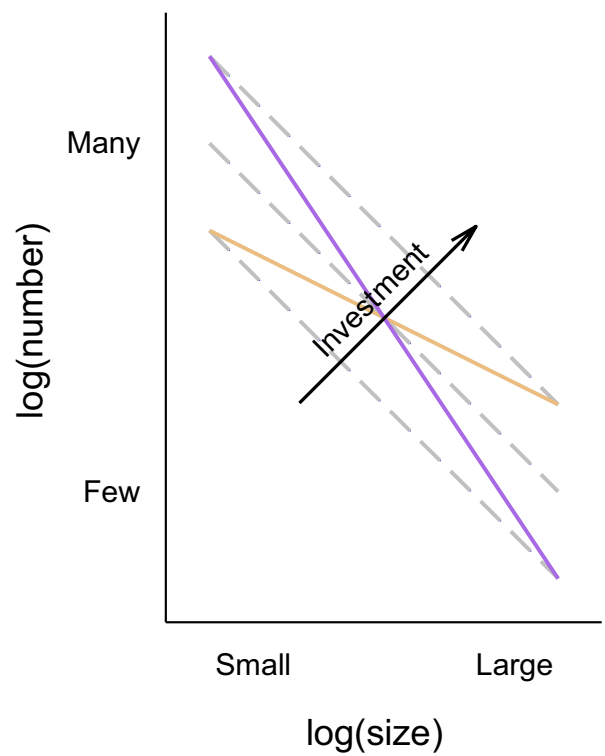

FIGURE 1 Consequences of changes in seed investment for number-size relations among individuals or species. Each dashed grey line depicts the feasible combinations of seed number, $N$, and size, $S$, for a specific investment, $I$, in seed production (i.e. $N=I S^{-1}$, or $\log N=\log I-[1] \log S)$. The different grey lines indicate the effect of differing seed investment on these relations. The coloured lines represent cases in which individuals/species with more seed investment allocate disproportionately to larger seeds (gold, log-log slope $>-1$ ) or to more seeds (purple, log-log slope $<-1$ ) compared to those with less seed investment

the incremental (marginal) maternal fitness benefit of increased seed size and the incremental cost of decreased seed number (and vice versa: Lloyd, 1987). When seed investment is also subject to selection (e.g. optimization of overall reproductive investment and (or) of resource allocation to seed production vs. seed siring), the course of evolution depends additionally on the marginal benefits of increased seed investment (Venable, 1992) and the relative additive genetic variances of seed investment, seed number and size (Worley et al., 2003). In contrast, in the simplest agricultural context (i.e. yield maximization), yield,

$$
Y=I D
$$

varies with seed investment, I $(=S \cdot N)$, but not among the feasible seed number-size combinations for a given seed investment and plant density ( $D$; plants per harvested area). Thus, successful artificial selection for greater yield necessarily increases seed investment, I, which should therefore be a pervasive feature of grain crops. Whether this evolution also entails increased seed number, size or both depends on their specific additional benefits. Minimally, increased seed mass seems likely, given its positive influences on sowing success, seedling survival and harvest quality (Cunniff et al., 2014; Leishman et al., 2000; Preece et al., 2017; Purugganan \& Fuller, 2009; Sadras, 2007).

To the extent that crop species in different clades experienced similar initial progenitor filtering and subsequent domestication selection, a suite of analogous traits could evolve that are more similar among crops than among their wild ancestors, or a 'domestication syndrome' (Fuller, 2007; Hammer, 1984; Harlan et al., 1973; Meyer et al., 2012; Preece et al., 2017). The details of this syndrome would depend on the consistency of domestication regimes (cultivation conditions, progenitor filtering, artificial selection) among species. Similar environments and qualitative farmer preferences (e.g. for more investment in larger seeds) should cause parallel evolution of a general domestication syndrome. If agricultural environments and practices specifically target a common phenotype, convergent evolution should generate a specific domestication syndrome. A general domestication syndrome is evident for crops in the Poaceae and Fabaceae (e.g. delayed dispersal of weakly defended seeds with limited dormancy: Fuller, 2007; Meyer et al., 2012), but seems less apparent among crops from other clades (Meyer et al., 2012).

Despite extensive archaeological and genetic research concerning domestication of major grain crops (Abbo \& Gopher, 2017; Purugganan \& Fuller, 2009), few comparative ecological studies (e.g. phenotypic space analyses) have assessed similarities and differences of components of seed production between grain-crop and wild species (although see Martin, 2021; Milla et al., 2015, 2018; Preece et al., 2015, 2017). Particularly lacking are comparisons of wild and grain-crop species concerning the association of seed investment and seed number-size relations (e.g. Gambín \& Borrás, 2010; Sadras, 2007), despite its central role in domestication selection of seed production. To examine these features of domestication, we address four related objectives based on published records for wild and grain-crop species with annual life cycles. First, we (1) characterize the overall differences between wild and grain-crop species with respect to total seed number per plant $(N)$, the mean mass of individual seeds $(S)$ and the total mass investment in seed production ( $I$ ). We then assess the contributions of (2a) progenitor filtering and ( $2 \mathrm{~b}$ ) domestication selection (improvement) to the observed differences. In addition, we (3) consider the extent to which the seed-production characteristics of contemporary grain crops transcend the boundaries of nature, as represented by the range of variation evident among wild species. Based on this evidence, we finally consider (4) the extent to which grain-crop characteristics constitute a domestication syndrome, and if so whether the syndrome is general or specific.

\section{2 | MATERIALS AND METHODS}

\section{1 | Data collection}

We surveyed published studies of annual wild and grain-crop species that reported mean per-seed mass ( $\mathrm{mg}$ ) and seed number per individual plant. The focus on annual species reflects three desirable characteristics. For annuals, the time-scales of performance relevant for artificial selection of crops (annual yield) and natural selection of wild and crop species (lifetime genetic contributions) are equivalent. In addition, total seed investment by annuals involves only resource 
acquisition during the current growing season, rather than possible input from stored resources (Aarssen \& Jordan, 2001). Finally, annuals are the progenitors of most staple grain crops, which have been subject to most concerted domestication (Harlan, 1992).

During 2012, we searched for data sources using Google Scholar. General search terms included 'seed number', 'seed weight', 'seed mass' and 'annual plant'. We also included terms such as 'wild soybean', 'cultivated soybean', etc. to enhance the representation of grain crops and their relatives. Publications identified during these searches were scanned for relevant measurements of at least two of the following variables: seed number per plant $(N)$, per-seed mass $(S)$ and total seed mass per plant (I). If the value for one variable was missing, it was calculated from the other two, based on $I=N \cdot S$. Data were gathered from tables, extracted from figures using image software (http://rsbweb.nih.gov/ij/index.html), or obtained from authors when only summary statistics were published. In addition to the data located by these searches, we included more recent measurements reported by Preece et al. (2017). In total, 11 crop species are also represented by observations of conspecific wild varieties or subspecies, which we consider as separate 'species' in the analyses. Measurements for wild representatives of these grain crops were included only if the article stated that the specimens were the wild ancestor of the crop, a wild variety or a wild population. Many surveyed studies provided data for multiple years, populations, varieties or trials (collectively referred to as 'trials'), which we recorded separately. The final database includes 1,461 records from 139 studies (see Data sources section, Garibaldi et al., 2021) for 136 species from 15 families, comprising 49 grain-crop and 87 wild species (Figure S1). In all, 64 species belong to the Fabaceae (32) or Poaceae (32). Of the 136 species, 89 were examined by one study and only eight of the remaining 47 species were examined by $>3$ studies. Of the 139 studies, 114 examined a single species, and 10 of the 25 studies of multiple species involved multiple trials per species.

\subsection{Statistical analyses}

\subsection{1 | Phylogenetic relatedness}

Analyses of objectives 1-3 fit general linear models that quantified the effects of relevant independent variables on interspecific variation of the three measured seed-production traits (seed number per plant, mean per-seed mass, total seed investment; all $\log _{10}$ transformed). To account for possible lack of independence among species in these analyses associated with phylogenetic relatedness, the parameters of most models were estimated using generalized least squares after accounting for phylogenetic covariance among species (Paradis, 2012). These analyses were conducted with the gls function of the NLME package (version 3.1-150; Pinheiro et al., 2014) of $\mathrm{R}$ (version 4.0.2: $\mathrm{R}$ Core Team, 2020). As this program does not allow simultaneous consideration of phylogenetic covariance and intraspecific variation, these analyses involved the 136 species means.
Phylogenetic relatedness of the sampled species was represented by a tree with 136 tips (species) and 123 internal nodes based on Zanne et al.'s (2014) dated megatree for angiosperms (Figure S1). The accepted names for all species were identified using The Plant List (http://www.theplantlist.org/), which were then compared with the species included in Zanne et al.'s (2014) megatree. We represented the phylogenetic position of species missing from the megatree by that of their phylogenetically closest included relative. The megatree was then pruned to extract a dated phylogeny for just the species represented in the dataset (see Scholl et al., 2020 for a similar procedure). Finally, we included two refinements concerning Amaranthus and Sesamum species, which were not represented fully by Zanne et al. (2014). The topology and branch lengths for the 18 Amaranthus species were incorporated based on Waselkov et al. (2018). For Sesamum, we included S. alatum and S. radiatum in a polytomy with $S$. indicum, with branch lengths equal to half the 20.1 mya divergence age of Uncarina and Sesamum (Stevens, 2001).

Using this tree or subtrees appropriate for a particular objective, we analysed three evolutionary models of interspecific covariance, phylogenetic independence, Brownian motion and Grafen's model. The independence model specified no phylogenetic covariance among species. The Brownian motion model depicted the covariance between species $i$ and $j, V_{i j}=\sigma^{2} \cdot \delta_{i j}$, as increasing proportionally with the variance of a Brownian process, $\sigma^{2}$, and the phylogenetic distance between the root and the species' most recent common ancestor, $\delta_{i j}$ (Paradis, 2012). In contrast, Grafen's model represented branch length as the scaled number of descendant species subtended by a node minus one. This count was scaled so that the root has height one and the heights of other nodes were raised to power $\rho>0$, which was estimated from the data (Paradis, 2012). Phylogenetic covariance based on the Brownian and Grafen models was estimated using the corBrownian and corGrafen functions of the R APE package (version 5.4-1: Paradis et al., 2004). As AIC comparisons indicated that Brownian motion did not adequately represent phylogenetic covariance for any analysis, we do not mention those analyses further. Two variants of the analyses for phylogenetic independence and Grafen's model were considered that allowed either homogeneous or heterogeneous variances for different levels of categorical independent variables. We present the results for only the variance-covariance model with lowest AIC.

\subsection{2 | Objective-specific methods}

Objective 1: Characterize the overall seed-production differences between wild and grain-crop species-The complete sample of species means was used to compare wild and crop species with respect to both trait means and the covariation of seed number per plant and mean per-seed mass. All analyses included species type (wild or crop) as a categorical factor. The analysis of covariation considered $\log _{10}$ (seed number per plant) as the dependent variable and $\log _{10}$ (perseed mass) as a continuous independent variable, in addition to species type and the species type $\times \log _{10}$ (per-seed mass) interaction. 
Back-transformation of the regression relation for a specific species type, $\log _{10} N=a+b \cdot \log _{10} S$, yields $N=10^{a} S^{b}$, which is a general version of Equation 1, with $10^{a}$ estimating mean $I$ and $b$ estimating the scaling exponent of the number-size relation. Analysis of this relation did not include measurements of total seed investment, as it was not estimated independently of seed number and size for some species.

To illustrate the relation between seed number and mass, which are both random variables, we depict the first principal component of their correlation matrix, estimated separately for wild and crop species. The first principal component is equivalent to a major axis model II regression (Legendre \& Legendre, 2012). Principal component analysis involved the phyl.pca function of the R PHYTOoLs package (version 0.7-70: Revell, 2012), which accounts for phylogenetic relatedness.

Objective 2a: Evidence of progenitor filtering of seed-production traits-Ideally, the extent to which domestication began with a nonrandom subset of wild species would be assessed by comparing traits between crop progenitors and species not subsequently subject to domestication when domestication began. In the absence of relevant historical measurements, we compared the trait means of wild species between genera with sampled grain-crop species (18 genera, 44 species) and those without grain-crop species (33 genera, 43 species). This comparison between genus types involved the generalized least squares methods described above and a phylogeny for only the 87 relevant species.

Objective 2b: Evidence of domestication selection on seedproduction traits-In this case, the ideal comparison would contrast the contemporary trait means of grain crops with the historical means of their progenitors. As the historical traits of many crop progenitors are unknown, contemporary wild congeners of crop species provide conservative proxies. Using this approach, we compared seed-production characteristics between congeneric wild $(n=44)$ and grain-crop species $(n=28)$ for 18 genera. These analyses involved a general linear model with genus as a fixed blocking factor to impose within-genus comparison of species type (wild, crop). The phylogenetically independent observation model (with heterogeneous variances) was used for these analyses, as it fit better than the
Grafen model, indicating that the explicit inclusion of genus largely accounted for phylogenetic relatedness.

Objective 3: Boundaries of nature-We characterized the boundaries of nature as the $95 \%$ inclusion ellipse for mean of seed number per plant and per-seed mass ( $\log _{10}$-transformed) for the sampled wild species, given a bivariate normal distribution. This ellipse was identified using the ellipse function of the R MIXTOoLs package (version 1.2.0). If crop species disproportionately transcend this range of variation, more than $5 \%$ of their means should lie outside the ellipse.

Objective 4: Domestication syndrome-Parallel or convergent evolution could generate different domestication syndromes. Parallel evolution would create a general domestication syndrome whereby grain-crop species differ in a qualitatively similar manner (e.g. larger seeds) from wild species. Results from the analyses for Objectives 1 and 2 are all relevant in this context. In contrast, a specific syndrome requires convergence among crop species to a similar phenotype. In this case, the among-species component of overall trait variation should additionally be smaller for crop species than for wild species. We tested the latter expectation for the complete sample of 1,461 trials with the glimmix procedure of SAS/STAT 15.1 (SAS Institute Inc., 2018), which allows between-group comparison of variance components with likelihood-ratio tests. For each of the three seed traits, the analysis included species type (crop or wild) as the fixed factor, and species within species type, studies nested within species, and trials for individual species within studies as random factors, with separate estimates of the associated variance components for each species type. Because these variance components were estimated for log trait values, their magnitudes are unaffected by differences in trait means (Lewontin, 1966) and can be compared directly.

\section{3 | RESULTS}

Based on 136 annual species, individual plants of grain crops invest more mass in seed production than those of wild species, on average (Objective 1: Table 1; Figure 2a, compare means in relation to grey

TABLE 1 Overall test statistics for comparisons of species mean seed number per plant $(N)$, per-seed mass $(S)$ and total seed investment $(I=N \cdot S)$ relevant to Objectives 1 (characterize mean wild-crop differences), 2 a (progenitor filtering) and $2 \mathrm{~b}$ (domestication selection), and of the among-species variance component relevant to Objective 4 (domestication syndrome). Effects considered include species type (wild or grain-crop), genus type (with or without sampled grain-crops) and the genus to which species belong. Analyses of mean differences accounted for phylogenetic relatedness by either estimating the interspecific phylogenetic correlation (Grafen model: Obj. 1, 2a) or by including genus as an independent variable (Obj. $2 \mathrm{~b}$ )

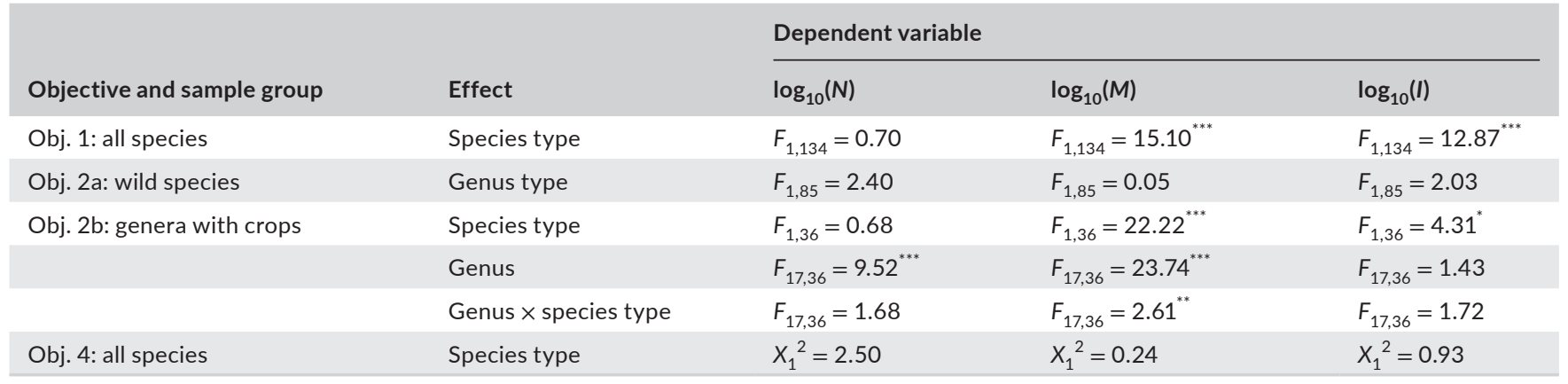

${ }^{*} p<0.05 ; ;{ }^{* *} p<0.01 ; ;{ }^{* * *} p<0.001$ 


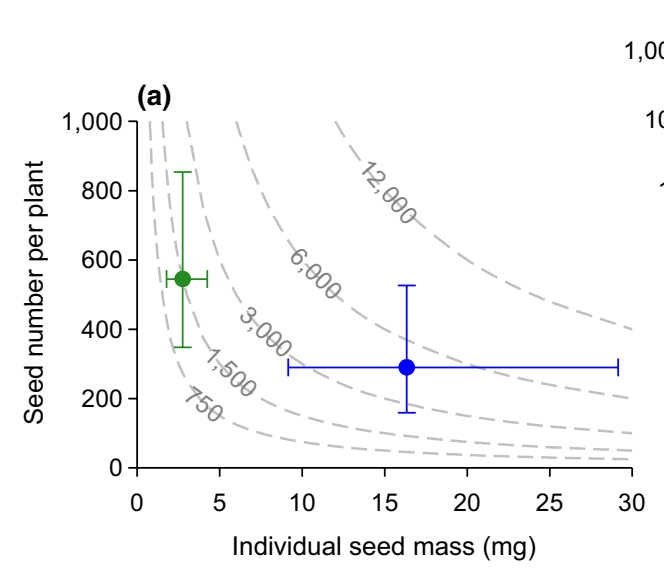

(b)

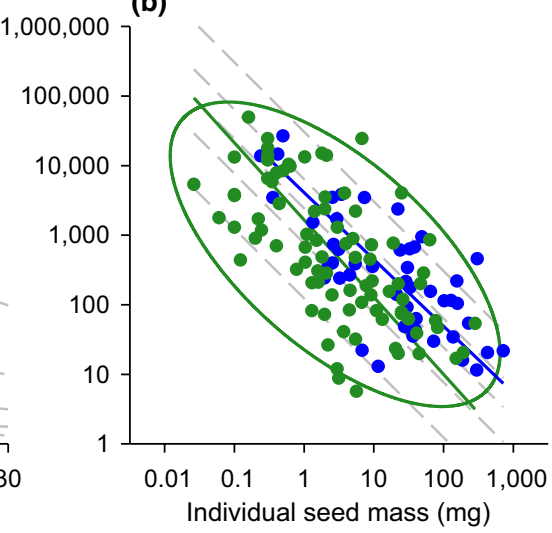

FIGURE 2 Relations of (a) overall mean ( $\pm 95 \%$ confidence interval) and (b) individual species mean seed number per plant and perseed mass for 87 wild species (green) and 49 grain-crop species (blue). In panel (a), mean seed investment for wild and crop species can be compared with reference to the dashed grey lines, which indicate isoclines of indicated investments (the number-size product: $\mathrm{mg}$ ). Panel (b) includes major axis regression lines for each species type and the green ellipse encloses $95 \%$ of the observations for the wild species (note the $\log _{10}$ scaling). The dashed grey isoclines represent the 5, 25, 50, 75 and $95 \%$ quantiles (from left to right) of interspecific variation in seed investment for all species, for which the slope is -1

investment isoclines). This difference largely reflects the production of heavier individual seeds by grain crops, as total seed number per plant did not differ statistically between crop and wild species (Table 1; Figure 2a). Seed number varied strongly and negatively with per-seed mass $\left(F_{1,133}=67.21, p<0.001\right)$. Overall, seed number per plant varied inversely among species with mean per-seed mass (major axis slope $=-1.046$ ), so interspecific variation aligned largely along seed investment isoclines for all species (Figure $2 b$ ). This relation did not differ statistically between wild and grain-crop species (interaction, $F_{1,132}=0.29, p>0.5$ : generalized least-squares partial regression coefficients [95\% confidence intervals], wild species, -0.597 [-0.793, -0.402]; crops, -0.666 [-0.868, -0.463]: major axis slopes, wild species, -1.109 ; crops, -0.961 : Objective 1).

The 87 wild species did not exhibit evidence of progenitor filtering (Objective 2a). Specifically, mean total seed number, per-seed mass and total seed investment did not differ statistically for wild species between genera that also include sampled grain-crop species and those that do not (Table 1).

In contrast, differences between wild and grain-crop species in genera with both species types indicated considerable domestication selection (Objective 2b). Overall, seed number per plant and per-seed mass varied extensively among genera, unlike total seed investment (Table 1, Obj. 2b, Genus; Figure 3). Comparisons between wild and crop species detected heavier seeds and somewhat greater total seed investment for crop species, but no general difference in total seed number per plant (Table 1, Obj. 2b, Species type). Contrasts of wild and crop species also differed among genera for per-seed mass, but not for seed number or investment (Table 1, Obj. 2b, Genus x Species type interactions; Figure 3). Seeds of graincrop species were numerically heavier than those of wild species, on average, in 16 of the 18 genera, with $>18$-fold differences in Helianthus, Hordeum and Vicia. In contrast, individuals of grain-crop species produced numerically more seeds that wild species in eight

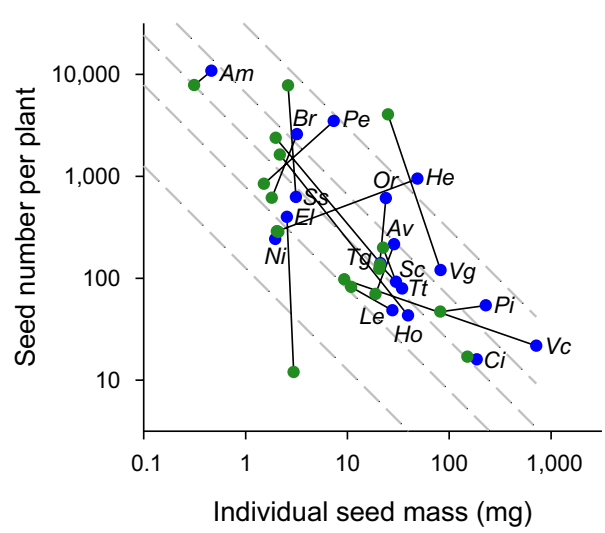

FIGURE 3 Contrasts of mean seed number per plant and perseed mass between wild and grain-crop species within 18 genera. Linked green and blue symbols, respectively, represent the means of wild and crop species sampled for a genus. Letters beside blue symbols identify the associated genus: Am, Amaranthus; Av, Avena; Br, Brassica; Ci, Cicer; El, Eleusine; He, Helianthus; Ho, Hordeum; Le, Lens; Ni, Nigella; Or, Oryza; Pe, Pennisetum; Pi, Pisum; Sc, Secale; Ss, Sesamum; Tg, Trigonella; Tt, Triticum; Vc, Vicia; Vg, Vigna. The dashed grey isoclines represent the 5, 25, 50, 75 and 95\% quantiles (from left to right) of interspecific variation in seed investment, for which the log-log slope is -1 . Note the $\log _{10}$ scaling

genera, but fewer seeds in 10 genera, indicating more heterogeneous changes than for per-seed mass. Despite evidence of domestication selection, number-mass means for grain-crop species do not lie disproportionately outside the $95 \%$ inclusion ellipse for wild species (Figure 2b), and so do not transcend the boundaries of nature (Objective 3).

Seed characteristics of the 136 sampled species support general, but not specific, features of a domestication syndrome (Objective 4). As described above, grain-crop species commonly produce heavier 
individual seeds and a greater total seed mass than wild species (Figures 2a and 3). However, contrary to expectations for convergent evolution, differences among grain-crop species do not account for less of the overall variances in seed number, mass or investment than for wild species (Table 1; Figure 4). Furthermore, differences among grain-crop species account for more of the total trait variance than intraspecific variation for both seed number per plant and per-seed mass (Figure 4). Thus, domestication selection of per-seed mass and seed investment maintained heterogeneity among graincrop species, rather than promoting convergence towards a common crop phenotype.

\section{4 | DISCUSSION}

Comparative analysis of 87 wild species and 49 grain-crop species revealed mixed influences of domestication on seed-production characteristics. On average, grain-crop species invest greater mass in seed production per plant in association with production of larger, but not more, seeds (Figure 2a). This difference largely reflects responses by grain-crop species to domestication selection (Figure 3), as no effects of initial progenitor filtering were evident (Table 1). The resulting crop evolution did not alter the interspecific seed numbersize relation compared to that among wild species (Figure $2 b$ ). Correspondingly, seed number-size phenotypes of grain-crop species lie within the boundaries of nature represented by the range of variation among wild species (Figure 2a). Greater total seed investment and heavier seeds (Figure 2 ) are features of a general domestication syndrome, but similar interspecific variation between grain-crop and wild species indicates that crop evolution has not targeted a specific syndrome.

\section{1 | Progenitor filtering}

The lack of evidence of progenitor filtering (Table 1, Obj. 2a) could reflect either of two aspects of the data. Progenitor filtering could have been involved early during the domestication of the grain-crop species included in our sample, but it involved traits other than seeds per plant, per-seed mass and seed investment (see Preece et al., 2018). For example, preliminary analyses of toxicity for the sampled species suggest less toxicity among wild species in genera with grain-crop species than in genera without crop species ( $M$. Strelin, unpubl. data). Alternatively, the traits of contemporary wild species belonging to genera that also include crop species may be poor surrogates of the phenotypes of crop progenitors. Importantly, when grain-crop progenitors were first identified as worthy of cultivation they may have differed in desirable characteristics from both congeners and species in other genera. In addition, traits of non-progenitor congeners may have evolved since domestication of related grain-crop species was initiated, obscuring differences that may have existed when domestication began.

Despite the preceding qualification, our results may be representative of a generally limited contribution of progenitor filtering to differences in seed-production traits between grain-crops and wild species. Previous, more focused, common-garden studies comparing putative grain-crop progenitors and wild relatives with archaeological evidence of harvesting, but not of domestication, detected differences consistent with progenitor filtering in Poaceae, but not in Fabaceae (Cunniff et al., 2014; Preece et al., 2015). Among the Poaceae considered by those studies, crop progenitors had larger seeds than wild species, but seed number of progenitors was either equivalent (Cunniff et al., 2014) or less than that of wild species (Preece et al., 2015). Additionally, Preece et al. (2015) found no difference in seed investment between related progenitor and crop species or subspecies (not examined by Cunniff et al., 2014). This heterogeneous evidence suggests that progenitor filtering may have contributed to distinctive seed characteristics of some grain crops, but it has not been involved universally.

\subsection{Domestication selection}

Unlike assessment of progenitor filtering, intra-generic comparison of grain-crop and wild species revealed clear evidence of domestication selection on seed-production traits. The generally greater total
FIGURE 4 Comparison of variance components ( $\pm 95 \%$ confidence intervals) among species and among and within studies of individual species for seed number per plant, per-seed mass and total seed investment (the number-size product) between wild and grain-crop species. Based on 412 records for 87 wild species and 1,049 records for 49 graincrop species
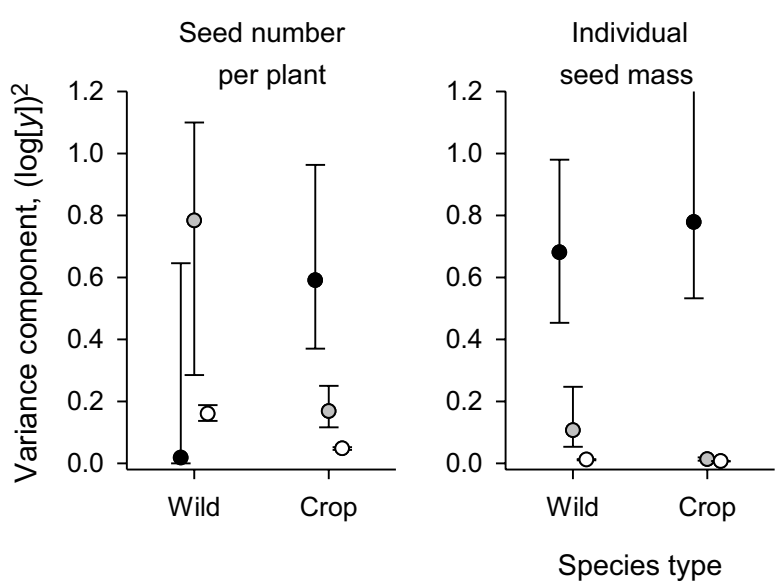
seed investment by grain-crop species is an expected outcome of artificial selection targeting increased collective yield (see Equation 2). Greater total investment in seed mass could arise from combined net increases in four components of plant resource economy; overall plant mass and the hierarchical relative allocations to reproductive versus vegetative function, female versus male function and seeds versus accessory tissues (Harlan, 1992; Milla \& Matesanz, 2017; Preece et al., 2017; Stitzer \& Ross-Ibarra, 2018). These changes can arise from direct selection for increased yield, or as a correlated response to selection for other traits. An example of the latter is increased relative allocation to female function resulting from selection for self-fertilizing varieties (see Charnov, 1987; Dempewolf et al., 2012; McKone, 1987). This variety of options suggests that the general increase in seed investment likely involved heterogeneous responses of resource investment and allocation to domestication among grain-crop lineages.

Although artificial selection that targets increased seed yield should not, by itself, have also selected for larger seeds (see explanation involving Equation 2), that change commonly distinguishes grain crops from wild relatives (Table 1, Obj. 2b; Figure 3: Preece et al., 2017; Purugganan \& Fuller, 2009). Instead, increased perseed mass could reflect additional aspects of artificial and natural selection during domestication. Artificial selection should have had contrasting consequences for seed number per plant and per-seed mass. Independent of its contribution to seed investment, seed number per plant may often be irrelevant to artificial selection of grain-crops, because agricultural propagation of the next generation involves a minor fraction of a crop's bulk production, the majority being used for human purposes. The heterogeneous changes in seed number during domestication (Figure 3) are consistent with this practice. In contrast, breeders could have imposed indirect artificial selection on per-seed mass by choosing propagation stock based on correlated aspects of seed quality related to seed growth capacity or nutritional value. Specifically, per-seed mass often varies positively within species with seedling emergence and establishment (Preece et al., 2017; Purugganan \& Fuller, 2009; Sadras, 2007) and (or) with the concentrations of beneficial constituents of human and livestock diets (e.g. Kulwal \& Mhase, 2017; Meru et al., 2018; Ries \& Everson, 1973; Wang et al., 2020). Thus, artificial selection for seed quality could have induced evolution of larger seeds, even if seed size was not the explicit selection target.

Natural selection could also have contributed to the evolution of larger seeds in grain crops if domestication increased the optimal seed size that maximizes individual fitness, given the within-plant number-size allocation constraint. The general interspecific association of greater seed investment and seed mass by grain crops (Table 1, Obj. 1, 2b) suggests that artificial selection for enhanced yield shifted the seed-size optimum, causing coincident natural selection (see Venable, 1992). The novel agricultural environments experienced by crops could also have imposed unintended natural selection during domestication. In particular, the positive association of seed mass and seedling establishment (Leishman et al., 2000; Purugganan \& Fuller, 2009; Sadras, 2007) could have favoured natural selection of larger seeds to contend with aggravated intraspecific competition associated with cultivation (Preece et al., 2017; also see Turnbull et al., 1999). In either case, increased seed investment would have allowed evolution of seed size with heterogeneous change in seed number, despite individual plants being subject to a number-size trade-off.

\section{3 | Boundaries of nature}

During more than 10,000 years (generations) of domestication effort, seed evolution in annual grain-crop species has not expanded the phenotypic space they occupy compared to that of wild plants. Specifically, although grain crops generally produce large seeds relative to wild species, their mean per-seed mass does not lie disproportionately outside the $95 \%$ inclusion ellipse for wild species (Figure 2b). Explanation of this constrained evolution likely lies in the consistent interspecific seed number-size relation for both graincrop and wild species, the slope of which largely parallels isoclines of fixed seed investment (Figure 2b). This consistency, despite the generally greater per-seed mass of grain crops, suggests a boundary of nature for annual plants associated with a pervasive upper limit on relative seed investment arising from the requirement that resources must also be expended on other plant functions. Such boundedness has also been reported for other trait relations, such as nitrogen content and specific leaf area (Milla et al., 2015), nitrogen use for photosynthesis (Rotundo \& Cipriotti, 2017), and plant canopy height, leaf nitrogen content and seed dry mass (Milla et al., 2018).

\section{4 | Domestication syndrome}

Comparison of seed-production characteristics by congeneric wild and grain-crop species suggests that domestication of multiple annual grain crops has, at most, involved parallel, rather than convergent, evolution. Although grain-crop species generally produce a greater mass of larger seeds than related wild species (Figure 3), this evolution has not reduced interspecific variation among grain crops (Figure 4). The latter result is inconsistent with convergent evolution. Thus, the generally greater seed investment and per-seed mass for grain-crop species compared to wild relatives suggests roughly parallel evolution for these traits during domestication from contrasting initial states. These patterns are consistent with a general domestication syndrome (greater mass of larger seeds), rather than a specific syndrome represented by similar investment and per-seed mass among crop species.

\section{5 | CONCLUSIONS}

Results of this study suggest both common and heterogeneous aspects of the domestication of annual grain crops. Differences between wild and crop species in seed number and per-seed and total seed mass 
seem to have arisen largely in response to domestication selection, rather than from initial progenitor filtering of candidate crops. In keeping with the general agricultural objective of enhancing yield, grain-crop evolution tended to increase total mass investment in seed production. However, yield improvement seems subject to an upper limit that is also evident among wild species (a boundary of nature). Within this apparent constraint, yield improvement typically involved increased per-seed mass, in contrast to varied changes among species in seed number per plant. The magnitude of shifts in seed-production characteristics differed considerably among clades, even among those with a long history of domestication (e.g. Triticum vs. Hordeum, Figure 3). Given this heterogeneity, fecundity characteristics seem to represent a minor component of an interspecific domestication syndrome.

\section{ACKNOWLEDGEMENTS}

We thank Adam Martin, Angela Moles and an anonymous reviewer for considered comments that improved this paper. Funding for this research was provided by the Argentine Agencia Nacional de Promoción Científica y Tecnológica (PICT 2013-1079 [L.A.G.] and PICT 2015-2333 [M.A.A.]) and Consejo Nacional de Investigaciones Científicas y Técnicas (PIP 114-201101-00201: L.A.G.), the Universidad Nacional del Comahue (B152/04: M.A.A.), the Universidad Nacional de Río Negro (PI 40-B-399: L.A.G.) and the Natural Sciences and Engineering Research Council of Canada (RGPIN/107375-2012: L.D.H.).

\section{AUTHORS' CONTRIBUTIONS}

L.A.G., M.A.A. and L.D.H. designed the study; L.A.G., A.S. and M.M.S. collected the data; G.G. assembled the phylogenetic tree; L.A.G. and L.D.H. conducted the data analyses and wrote the initial draft, and all authors revised the final manuscript.

\section{DATA AVAILABILITY STATEMENT}

Data deposited in the Dryad Digital Repository https://doi. org/10.5061/dryad.jsxksn092 (Garibaldi et al., 2021).

\section{ORCID}

Lucas A. Garibaldi iD https://orcid.org/0000-0003-0725-4049

Marcelo A. Aizen iD https://orcid.org/0000-0001-9079-9749

Agustín Sáez iD https://orcid.org/0000-0002-6461-2888

Gabriela Gleiser iD https://orcid.org/0000-0002-4178-6703

Marina M. Strelin (D) https://orcid.org/0000-0002-8237-7746

Lawrence D. Harder (D) https://orcid.org/0000-0002-2303-5076

\section{REFERENCES}

Aarssen, L. W., \& Jordan, C. Y. (2001). Between-species patterns of covariation in plant size, seed size and fecundity in monocarpic herbs. Écoscience, 8, 471-477. https://doi.org/10.1080/11956 860.2001.11682677

Abbo, S., \& Gopher, A. (2017). Near Eastern plant domestication: A history of thought. Trends in Plant Science, 22, 491-511. https://doi. org/10.1016/j.tplants.2017.03.010

Anten, N. P. R., \& Vermeulen, P. J. (2016). Tragedies and crops: Understanding natural selection to improve cropping systems.
Trends in Ecology \& Evolution, 31, 429-439. https://doi.org/10.1016/j. tree.2016.02.010

Brown, T. A., Jones, M. K., Powell, W., \& Allaby, R. G. (2009). The complex origins of domesticated crops in the Fertile Crescent. Trends in Ecology \& Evolution, 24, 103-109. https://doi.org/10.1016/j.tree.2008.09.008

Charnov, E. L. (1987). On sex allocation and selfing in higher plants. Evolutionary Ecology, 1, 30-36. https://doi.org/10.1007/BF02067266

Cunniff, J., Wilkinson, S., Charles, M., Jones, G., Rees, M., \& Osborne, C. P. (2014). Functional traits differ between cereal crop progenitors and other wild grasses gathered in the neolithic fertile crescent. PLoS ONE, 9, e87586. https://doi.org/10.1371/journal.pone.0087586

Dempewolf, H., Hodgins, K. A., Rummell, S. E., Ellstrand, N. C., \& Rieseberg, L. H. (2012). Reproductive isolation during domestication. The Plant Cell, 24, 2710-2717. https://doi.org/10.1105/ tpc.112.100115

Fuller, D. Q. (2007). Contrasting patterns in crop domestication and domestication rates: Recent archaeobotanical insights from the Old World. Annals of Botany, 100, 903-924. https://doi.org/10.1093/aob/ $\mathrm{mcm} 048$

Gambín, B. L., \& Borrás, L. (2010). Resource distribution and the tradeoff between seed number and seed weight: A comparison across crop species. Annals of Applied Biology, 156, 91-102. https://doi. org/10.1111/j.1744-7348.2009.00367.x

Garibaldi, L. A., Aizen, M. A., Sáez, A., Gleiser, G., Strelin, M., \& Harder, L. D. (2021). Data from: The influences of progenitor filtering, domestication selection and the boundaries of nature on the domestication of grain crops. Dryad Digital Repository, https://doi.org/10.5061/ dryad.jsxksn092

Hammer, K. (1984). Das Domestikationssyndrom. Die Kulturpflanze, 32, 11-34. https://doi.org/10.1007/BF02098682

Harlan, J. R., de Wet, J. M. J., \& Price, E. G. (1973). Comparative evolution of cereals. Evolution, 27, 311-325. https://doi.org/10.2307/2406971

Harlan, J. R. (1992). Crops and man (2nd ed.). American Society of Agronomy and Crop Science Society of America.

Henery, M. L., \& Westoby, M. (2001). Seed mass and seed nutrient content as predictors of seed output variation between species. Oikos, 92, 479-490. https://doi.org/10.1034/j.1600-0706.2001.920309.x

Khoury, C. K., Bjorkman, A. D., Dempewolf, H., Ramirez-Villegas, J., Guarino, L., Jarvis, A., Rieseberg, L. H., \& Struik, P. C. (2014). Increasing homogeneity in global food supplies and the implications for food security. Proceedings of the National Academy of Sciences of the United States of America, 111, 4001-4006. https://doi.org/10.1073/ pnas.1313490111

Kluyver, T. A., Jones, G., Pujol, B., Bennett, C., Mockford, E. J., Charles, M., Rees, M., \& Osborne, C. P. (2017). Unconscious selection drove seed enlargement in vegetable crops. Evolution Letters, 1, 64-72. https://doi.org/10.1002/evl3.6

Kulwal, P. L., \& Mhase, L. B. (2017). Protein content exhibits a significant positive correlation with seed weight in chickpea germplasm collection. Plant Genetic Resources, 15, 283-285. https://doi.org/10.1017/ S147926211500060X

Legendre, P., \& Legendre, L. (2012). Numerical ecology (3rd ed.). Elsevier. Leishman, M. R., Wright, I. J., Moles, A. T., Westoby, M., \& Fenner, M. (2000). The evolutionary ecology of seed size. In M. Fenner (Ed.), Seeds: The ecology of regeneration in plant communities (pp. 31-57). CAB International.

Lewontin, R. C. (1966). On the measurement of relative variability. Systematic Zoology, 15, 141-142. https://doi.org/10.2307/sysbi o/15.2.141

Lloyd, D. G. (1987). Selection of offspring size at independence and other size-versus-number strategies. The American Naturalist, 129, 800817. https://doi.org/10.1126/science.26.678.918

Lloyd, D. G. (1988). A general principle for the allocation of limited resources. Evolutionary Ecology, 2, 175-187. https://doi.org/10.1007/ BF02067276 
McKone, M. J. (1987). Sex allocation and outcrossing rate: A test of theoretical predictions using bromegrasses (Bromus). Evolution, 41, 591598. https://doi.org/10.1111/j.1558-5646.1987.tb05829.x

Martin, A. R. (2021). Crops and the seed mass-seed output trade-off in plants. International Journal of Plant Sciences, 182, 84-90. https://doi. org/10.1086/711472

Meru, G., Fu, Y., Leyva, D., Sarnoski, P., \& Yagiz, Y. (2018). Phenotypic relationships among oil, protein, fatty acid composition and seed size traits in Cucurbita pepo. Scientia Horticulturae, 233, 47-53. https://doi. org/10.1016/j.scienta.2018.01.030

Meyer, R. S., DuVal, A. E., \& Jensen, H. R. (2012). Patterns and processes in crop domestication: An historical review and quantitative analysis of 203 global food crops. New Phytologist, 196, 29-48. https://doi. org/10.1111/j.1469-8137.2012.04253.x

Milla, R., \& Matesanz, S. (2017). Growing larger with domestication: A matter of physiology, morphology or allocation? Plant Biology, 19, 475-483. https://doi.org/10.1111/plb.12545

Milla, R., Osborne, C. P., Turcotte, M. M., \& Violle, C. (2015). Plant domestication through an ecological lens. Trends in Ecology \& Evolution, 30, 463-469. https://doi.org/10.1016/j.tree.2015.06.006

Milla, R., Bastida, J. M., Turcotte, M. M., Jones, G., Violle, C., Osborne, C. P., Chacón-Labella, J., Sosinski, Ê. E., Kattge, J., Laughlin, D. C., Forey, E., Minden, V., Cornelissen, J. H. C., Amiaud, B., Kramer, K., Boenisch, G., He, T., Pillar, V. D., \& Byun, C. (2018). Phylogenetic patterns and phenotypic profiles of the species of plants and mammals farmed for food. Nature Ecology and Evolution, 2, 1808-1817. https:// doi.org/10.1038/s41559-018-0690-4

Moles, A. T., Falster, D. S., Leishman, M. R., \& Westoby, M. (2004). Smallseeded species produce more seeds per square metre of canopy per year, but not per individual per lifetime. Journal of Ecology, 92, 384396. https://doi.org/10.1111/j.0022-0477.2004.00880.x

Olsen, K. M., \& Wendel, J. F. (2013). A bountiful harvest: Genomic insights into crop domestication phenotypes. Annual Review of Plant Biology, 64, 47-70. https://doi.org/10.1146/annurev-arplant-05031 2-120048

Paradis, E. (2012). Analysis of phylogenetics and evolution with $R$ (2nd ed.). Publisher? https://doi.org/10.1007/978-1-4614-1743-9

Paradis, E., Claude, J., \& Strimmer, K. (2004). APE: Analyses of phylogenetics and evolution in R language. Bioinformatics, 20, 289-290. https://doi.org/10.1093/bioinformatics/btg412

Pinheiro, J., Bates, D., DebRoy, S., Sarkar, D., \& R Development Core Team. (2014). nlme: Linear and nonlinear mixed effects models. R package version 3.1-117.

Preece, C., Livarda, A., Wallace, M., Martin, G., Charles, M., Christin, P.A., Jones, G., Rees, M., \& Osborne, C. P. (2015). Were Fertile Crescent crop progenitors higher yielding than other wild species that were never domesticated? New Phytologist, 207, 905-913. https://doi. org/10.1111/nph.13353

Preece, C., Livarda, A., Christin, P.-A., Wallace, M., Martin, G., Charles, M., Jones, G., Rees, M., \& Osborne, C. P. (2017). How did the domestication of Fertile Crescent grain crops increase their yields? Functional Ecology, 31, 387-397. https://doi.org/10.1111/1365-2435.12760

Preece, C., Clamp, N. F., Warham, G., Charles, M., Rees, M., Jones, G., \& Osborne, C. P. (2018). Cereal progenitors differ in stand harvest characteristics from related wild grasses. Journal of Ecology, 106, 12861297. https://doi.org/10.1111/1365-2745.12905

Purugganan, M. D., \& Fuller, D. Q. (2009). The nature of selection during plant domestication. Nature, 457, 843-848. https://doi.org/10.1038/ nature07895

R Core Team. (2020). R: A language and environment for statistical computing. R Foundation for Statistical Computing.

Revell, L. J. (2012). phytools: An R package for phylogenetic comparative biology (and other things). Methods in Ecology and Evolution, 3, 217223. https://doi.org/10.1111/j.2041-210X.2011.00169.x
Ries, S. K., \& Everson, E. H. (1973). Protein content and seed size relationships with seedling vigor of wheat cultivars. Agronomy Journal, 65, 884-886. https://doi.org/10.2134/agronj1973.000219620065000 $60011 x$

Roberts, L. (2011). 9 Billion? Science, 333, 540-543. https://doi. org/10.1126/science.333.6042.540

Rotundo, J. L., \& Cipriotti, P. A. (2017). Biological limits on nitrogen use for plant photosynthesis: A quantitative revision comparing cultivated and wild species. New Phytologist, 214, 120-131. https://doi. org/10.1111/nph.14363

Sadras, V. O. (2007). Evolutionary aspects of the trade-off between seed size and number in crops. Field Crops Research, 100, 125-138. https:// doi.org/10.1016/j.fcr.2006.07.004

SAS Institute Inc. (2018). SAS/STAT® 15.1 user's guide. SAS Institute Inc.

Scholl, J. P., Calle, L., Miller, N., \& Venable, D. L. (2020). Offspring polymorphism and bet hedging: A large-scale, phylogenetic analysis. Ecology Letters, 23, 1223-1231. https://doi.org/10.1111/ele.13522

Smith, C. C., \& Fretwell, S. D. (1974). The optimal balance between size and number of offspring. The American Naturalist, 108, 499-506. https://doi.org/10.1086/282929

Stevens, P. F. (2001 onwards). Angiosperm Phylogeny Website. http:// www.mobot.org/MOBOT/research/APweb/

Stitzer, M. C., \& Ross-lbarra, J. (2018). Maize domestication and gene interaction. New Phytologist, 220, 395-408. https://doi.org/10.1111/ nph.15350

Turnbull, L. A., Rees, M., \& Crawley, M. J. (1999). Seed mass and the competition/colonization trade-off: A sowing experiment. Journal of Ecology, 87, 899-912. https://doi.org/10.1111/j.1365-2745.2004.00856.x

van Noordwijk, A. J., \& de Jong, G. (1986). Acquisition and allocation of resources: Their influence on variation in life history tactics. The American Naturalist, 128, 137-142. https://doi.org/10.1086/284547

Van Tassel, D. L., Dehaan, L. R., \& Cox, T. S. (2010). Missing domesticated plantforms:Canartificialselectionfillthegap? EvolutionaryApplications, 3, 434-452. https://doi.org/10.1111/j.1752-4571.2010.00132.x

Venable, L. D. (1992). Size-number trade-offs and the variation of seed size with plant resource status. The American Naturalist, 140, 287304. https://doi.org/10.1086/285413

Wang, S., Liu, S., Wang, J., Yokosho, K., Zhou, B., Yu, Y.-C., Liu, Z., Frommer, W. B., Ma, J. F., Chen, L.-Q., Guan, Y., Shou, H., \& Tian, Z. (2020). Simultaneous changes in seed size, oil content and protein content driven by selection of SWEET homologues during soybean domestication. National Science Review, 7, 1776-1786. https://doi. org/10.1093/nsr/nwaa110

Waselkov, K. E., Boleda, A. S., \& Olsen, K. M. (2018). A phylogeny of the genus Amaranthus (Amaranthaceae) based on several low-copy nuclear loci and chloroplast regions. Systematic Botany, 43, 439-458. https://doi.org/10.1600/036364418X697193

Worley, A. C., Houle, D., \& Barrett, S. C. H. (2003). Consequences of hierarchical allocation for the evolution of life-history traits. The American Naturalist, 161, 153-167. https://doi.org/10.1086/345461

Zanne, A. E., Tank, D. C., Cornwell, W. K., Eastman, J. M., Smith, S. A., FitzJohn, R. G., McGlinn, D. J., O'Meara, B. C., Moles, A. T., Reich, P. B., Royer, D. L., Soltis, D. E., Stevens, P. F., Westoby, M., Wright, I. J., Aarssen, L., Bertin, R. I., Calaminus, A., Govaerts, R., ... Beaulieu, J. M. (2014). Three keys to the radiation of angiosperms into freezing environments. Nature, 506, 89-92. https://doi.org/10.1038/nature12872

\section{DATA SOURCES}

Aarssen, L. W., \& Jordan, C. (2001). Between-species patterns of covariation in plant size, seed size and fecundity in monocarpic herbs. Écoscience, 8, 471-477. https://doi.org/10.1080/11956860.2001.11682677

Abdelhamid, M. T., Horiuchi, T., \& Oba, S. (2004). Composting of rice straw with oilseed rape cake and poultry manure and its effects on faba bean (Vicia faba 
L.) growth and soil properties. Bioresource Technology, 93, 183-189. https://doi. org/10.1016/j.biortech.2003.10.012

Agegenehu, M., \& Honermeier, B. (1997). Effects of seeding rates and nitrogen fertilization on seed yield, seed quality and yield components of false flax. Die Bodenkultur, 48, 15. https://diebodenkultur.boku.ac.at/volltexte/band-48/ heft-1/agegnehu.pdf

Ahmadian, A., Ghanbari, A., Galavi, M., \& Tavassoli, A. (2011). The interaction ef fect of water stress and manure on yield components, essential oil and chemical compositions of cumin (Cuminum cyminum). African Journal of Agricultural Research, 6, 2309-2315. https://doi.org/10.1055/s-0030-1264615

Akhalkatsi, M., \& Lösch, R. (2005). Water limitation effect on seed development and germination in Trigonella coerulea (Fabaceae). Flora, 200, 493-501. https://doi. org/10.1016/j.flora.2005.06.001

Alege, G. O., Akinyele, B. O., Ayodele, S. M., \& Ogbode, A. V. (2011). Taxonomic importance of the vegetative and pod characteristics in three Nigerian species of sesame. African Journal of Plant Science, 5, 213-217. https://academicjournals. org/article/article1379946080_Alege\%20et\%20al.pdf

Alghamdi, S. S. (2007). Genetic behavior of some selected faba bean genotypes. African Crop Science Conference Proceedings, 8, 709-714. https://www.resea rchgate.net/profile/Salem_Alghamdi/publication/237236311_Genetic_Behav ior_of_Some_Selected_Faba_Bean_Genotypes/links/Odeec52c9bcce9bc6800 0000/Genetic-Behavior-of-Some-Selected-Faba-Bean-Genotypes.pdf

Alonso-Blanco, C., Blankestijn-de Vries, H., Hanhart, C. J., \& Koornneef, M. (1999). Natural allelic variation at seed size loci in relation to other life history traits of Arabidopsis thaliana. Proceedings of the National Academy of Sciences of the United States of America, 96, 4710-4717. https://doi.org/10.1073/pnas.96. 8.4710

Altinok, S., Eroğdu, I., \& Rajcan, I. (2004). Morphology, forage and seed yield of soybean cultivars of different maturity grown as a forage crop in Turkey. Canadian Journal of Plant Science, 84, 181-186. https://doi.org/10.4141/P03-013

Andrade, F. H., \& Ferreiro, M. A. (1996). Reproductive growth of maize, sunflower and soybean at different source levels during grain filling. Field Crops Research, 48, 155-165. https://doi.org/10.1016/S0378-4290(96)01017-9

Ayanoğlu, F., Mert, A., Aslan, N., \& Gürbüz, B. (2002). Seed yields, yield components and essential oil of selected coriander (Coriandrum sativum L.) lines. Journal of Herbs, Spices \& Medicinal Plants, 9, 71-76. https://doi.org/10.1300/ J044v09n02_10

Bahraminejad, A., Mohammadi-Nejad, G., \& Abdul Khadir, M. (2011). Genetic diversity evaluation of cumin (Cumin cyminum L.) based on phenotypic characteristics. Australian Journal of Crop Science, 5, 304-310. http://www.cropj.com/ bahraminejad_3_5_2011_304_310.pdf

Bajehbaj, A. A. (2011). Effects of drought stress and different densities on oil yield and biomass yield of sunflower varieties. African Journal of Biotechnology, 10 5608-5613. https://doi.org/10.5897/AJB10.62

Basu, S. K., Acharya, S. N., Bandara, M. S., Friebel, D., \& Thomas, J. E. (2009). Effects of genotype and environment on seed and forage yield in fenugreek (Trigonella foenum-graecum L.) grown in western Canada. Australian Journal of Crop Science, 3, 305. http://www.cropj.com/saikat_3_6_2009_305_314.pdf

Bazzaz, F. A., \& Carlson, R. W. (1979). Photosynthetic contribution of flowers and seeds to reproductive effort of an annual colonizer. New Phytologist, 82, 223232. https://doi.org/10.1111/j.1469-8137.1979.tb07577.x

Benner, B. L. (1988). Effects of apex removal and nutrient supplementation on branching and seed production in Thlaspi arvense (Brassicaceae). American Journal of Botany, 75, 645-651. https://doi.org/10.1002/j.1537-2197.1988. tb13487.x

Berti, M., Wilckens, R., Fischer, S., Solis, A., \& Johnson, B. (2011). Seeding date influence on camelina seed yield, yield components, and oil content in Chile. Industrial Crops and Products, 34, 1358-1365. https://doi.org/10.1016/j.inder op. 2010.12 .008

Bhargava, A., Shukla, S., \& Ohri, D. (2007). Genetic variability and interrelationship among various morphological and quality traits in quinoa (Chenopodium quinoa Willd.). Field Crops Research, 101, 104-116. https://doi.org/10.1016/j. fcr.2006.10.001

Bodega, J. L., De Dios, M. A., \& Pereyra Iraola, M. M. (2003). Sowing date affects yield components of canarygrass seed. Canadian Journal of Plant Science, 83 , 357-362. https://doi.org/10.4141/P02-037

Bole, J. B., \& Dubetz, S. (1978). Effects of various soil supplements and water stress on the yield and yield components of wheat. Canadian Journal of Soil Science, 58, 321-323. https://doi.org/10.4141/cjss78-038

Borrell, A. K., \& Hammer, G. L. (2000). Nitrogen dynamics and the physiological basis of stay-green in sorghum. Crop Science, 40, 1295-1307. https://doi. org/10.2135/cropsci2000.4051295x
Breznik, B., Germ, M., Gaberscik, A., \& Kreft, I. (2005). Combined effects of elevated UV-B radiation and the addition of selenium on common (Fagopyrum esculentum Moench) and tartary [Fagopyrum tataricum (L.) Gaertn.] buckwheat. Photosynthetica, 43, 583-589. https://doi.org/10.1007/s11099-005-0091-1

Brown, V. K., Gange, A. C., Evans, I. M., \& Storr, A. L. (1987). The effect of insect herbivory on the growth and reproduction of two annual Vicia species at different stages in plant succession. Journal of Ecology, 75, 1173-1189. https://doi. org $/ 10.2307 / 2260321$

Burnside, O. C., \& Wicks, G. A. (1969). Influence of weed competition on sorghum growth. Weed Science, 17, 332-334. https://doi.org/10.1017/S004317450 0054163

Caliskan, S., Arslan, M., Arioglu, H., \& Isler, N. (2004). Effect of planting method and plant population on growth and yield of sesame (Sesamum indicum L.) in a Mediterranean type of environment. Asian Journal of Plant Science, 3, 610-613. https://doi.org/10.3923/ajps.2004.610.613

Carrubba, A., la Torre, R., Prima, A. D., Saiano, F., \& Alonzo, G. (2002). Statistical analyses on the essential oil of Italian coriander (Coriandrum sativum L.) fruits of different ages and origins. Journal of Essential Oil Research, 14, 389-396. https://doi.org/10.1080/10412905.2002.9699899

Cheplick, G. P., \& Demetri, H. (1999). Impact of saltwater spray and sand deposition on the coastal annual Triplasis purpurea (Poaceae). American Journal of Botany, 86, 703-710. https://doi.org/10.2307/2656580

Çiftçi, V., Toğay, N., Toğay, Y., \& Doğan, Y. (2006). The effects of intercropping sowing systems with dry bean and maize on yield and some yield components. Journal of Agronomy, 5, 53-56. https://doi.org/10.3923/ja.2006.53.56

Conner, J. K., \& Zangori, L. A. (1998). Combined effects of water, nutrient, and UV-B stress on female fitness in Brassica (Brassicaceae). American Journal of Botany, 85, 925-931. https://doi.org/10.2307/2446358

Cox, W. J., \& Cherney, J. H. (2011). Growth and yield responses of soybean to row spacing and seeding rate. Agronomy Journal, 103, 123-128. https://doi. org/10.2134/agronj2010.0316

D'Antuono, L. F., Moretti, A., \& Lovato, A. F. (2002). Seed yield, yield components, oil content and essential oil content and composition of Nigella sativa L. and Nigella damascena L. Industrial Crops and Products, 15, 59-69. https://doi. org/10.1016/S0926-6690(01)00096-6

Dai, H. P., Shan, C. J., Wei, A. Z., Yang, T., Sa, W. Q., \& Feng, B. L. (2012). Leaf senescence and photosynthesis in foxtail millet [Setaria italica (L.) P. Beauv] varieties exposed to drought conditions. Australian Journal of Crop Science, 6, 232-237. http://www.cropj.com/dai 6_2_2012_232_237.pdf

Di, K., Stewart, C. N. Jr, Wei, W., Shen, B. C., Tang, Z. X., \& Ma, K. P. (2009). Fitness and maternal effects in hybrids formed between transgenic oilseed rape (Brassica napus L.) and wild brown mustard [B. juncea (L.) Czern et Coss.] in the field. Pest Management Science, 65, 753-760. https://doi.org/10.1002/ps.1749

Dornbos Jr., D. L., \& Mullen, R. E. (1991). Influence of stress during soybean seed fill on seed weight, germination, and seedling growth rate. Canadian Journal of Plant Science, 71, 373-383. https://doi.org/10.4141/cjps91-052

Dou, W., Wang, H., Yang, X., Xing, W., \& Liu, G. (2010). Effects of water depth and substrate type on growth dynamics and biomass allocation of Oryza rufipogon. Acta Ecologica Sinica, 30, 16-21. https://doi.org/10.1016/j.chnaes.2009.12.003

Ekin, Z., Tuncturk, M., \& Yilmaz, I. (2005). Evaluation of seed, oil yields and yield properties of different sunflower (Helianthus annus L.) hybrid varieties in Van, Turkey. Pakistan Journal of Biological Sciences, 8, 683-686. https://doi. org/10.3923/pjbs.2005.683.686

Elhani, S., Martos, V., Rharrabti, Y., Royo, C., \& del Moral, L. G. (2007). Contribution of main stem and tillers to durum wheat (Triticum turgidum L. var. durum) grain yield and its components grown in Mediterranean environments. Field Crops Research, 103, 25-35. https://doi.org/10.1016/j.fcr.2007.05.008

Elsahookie, M. M. (1978). Effects of varying row spacing on linseed yield and quality. Canadian Journal of Plant Science, 58, 935-937. https://doi.org/10.4141/ cjps78-144

Eslam, B. P. (2009). Evaluation of physiological indices, yield and its components as screening techniques for water deficit tolerance in oilseed rape cultivars. Journal of Agricultural Science and Technology, 11, 413-422. https://jast.modar es.ac.ir/article-23-6670-en.pdf

Eslam, B. P., Monirifar, H., \& Ghassemi, M. T. (2010). Evaluation of late season drought effects on seed and oil yields in spring safflower genotypes. Turkish Journal of Agriculture and Forestry, 34, 373-380. https://doi.org/10.3906/ tar-0904-43

Eslami, S. V., Gill, G. S., \& McDonald, G. (2010). Effect of water stress during seed development on morphometric characteristics and dormancy of wild radish (Raphanus raphanistrum L.) seeds. International Journal of Plant Production, 4, 159-168. https://doi.org/10.22069/ijpp.2012.692 
Farnsworth, E. J., \& Bazzaz, F. A. (1995). Inter-and intra-generic differences in growth, reproduction, and fitness of nine herbaceous annual species grown in elevated $\mathrm{CO}_{2}$ environments. Oecologia, 104, 454-466. https://doi. org/10.1007/BF00341343

Fenster, C. B., \& Galloway, L. F. (2000). Inbreeding and outbreeding depression in natural populations of Chamaecrista fasciculata (Fabaceae). Conservation Biology, 14, 1406-1412. https://doi.org/10.1046/j.1523-1739.2000.99234.x

Fortunel, C., Violle, C., Roumet, C., Buatois, B., Navas, M. L., \& Garnier, E. (2009). Allocation strategies and seed traits are hardly affected by nitrogen supply in 18 species differing in successional status. Perspectives in Plant Ecology, Evolution and Systematics, 11, 267-283. https://doi.org/10.1016/j.ppees.2009.04.003

Gaines, M. S., Vogt, K. J., Hamrick, J. L., \& Caldwell, J. (1974). Reproductive strategies and growth patterns in sunflowers (Helianthus). The American Naturalist, 108, 889-894. https://doi.org/10.1086/282967

Gambín, B. L., Borrás, L., \& Otegui, M. E. (2006). Source-sink relations and kernel weight differences in maize temperate hybrids. Field Crops Research, 95, 316326. https://doi.org/10.1016/j.fcr.2005.04.002

Gan, Y., Malhi, S. S., Kutcher, H. R., Brandt, S., \& Katepa-Mupondwa, F. (2008). Optimizing the production of Brassica juncea canola in comparison with other Brassica species, in different soil-climatic zones. Project Code: CARP, 11. https:// www.saskcanola.com/quadrant/System/research/reports/report-Gan-optim izing-long.pdf

Garg, N., \& Singla, R. (2004). Growth, photosynthesis, nodule nitrogen and carbon fixation in the chickpea cultivars under salt stress. Brazilian Journal of Plant Physiology, 16, 137-146. https://doi.org/10.1590/S1677-0420200400 0300003

Gebre-Mariam, H., \& Larter, E. N. (1979). Effect of plant density on yield, yield components and quality in triticale and Glenlea wheat. Canadian Journal of Plant Science, 59, 679-683. https://doi.org/10.4141/cjps79-106

Ghobadi, M., Bakhshandeh, M., Fathi, G., Gharineh, M. H., Alami-Said, K., Naderi, A. \& Ghobadi, M. E. (2006). Short and long periods of water stress during different growth stages of canola (Brassica napus L.): Effect on yield, yield components, seed oil and protein contents. Journal of Agronomy, 5, 336-341. https://doi. org/10.3923/ja.2006.336.341

Govahi, M., \& Saffari, M. (2006). Effect of potassium and sulphur fertilizers on yield, yield components and seed quality of spring canola (Brassica napus L.) seed Journal of Agronomy, 5, 577-582. https://doi.org/10.3923/ja.2006.577.582

Graf, R. J., \& Rowland, G. G. (1987). Effect of plant density on yield and components of yield of faba bean. Canadian Journal of Plant Science, 67, 1-10. https://doi. org/10.4141/cjps87-001

Hadi, H., Ghassemi-Golezani, K., Khoei, F. R., Valizadeh, M., \& Shakiba, M. R. (2006). Response of common bean (Phaseolus vulgaris) to different levels of shade. Journal of Agronomy, 5, 595-599. https://doi.org/10.3923/ja.2006.595.599

Hadi, M. R. H. S., Darzi, M. T., \& Gh, Z. (2012). Effects of irrigation treatment and Azospirillum inoculation on yield and yield component of black cumin (Nigella sativa L.). Journal of Medicinal Plants Research, 6, 4553-4561. https://doi. org/10.5897/JMPR12.228

Hansen, H. B., Møller, B., Andersen, S. B., Jørgensen, J. R., \& Hansen, Å. (2004). Grain characteristics, chemical composition, and functional properties of rye (Secale cereale L.) as influenced by genotype and harvest year. Journal of Agricultural and Food Chemistry, 52, 2282-2291. https://doi.org/10.1021/jf030 7191

Hawke, M. A., \& Maun, M. A. (1989). Intrapopulation variation in reproduction and seed mass of a beach annual; Cakile edentula var. lacustris. Journal of Coastal Research, 5, 103-112. https://www.jstor.org/stable/4297499

He, Z., Zhu, Q., Dabi, T., Li, D., Weigel, D., \& Lamb, C. (2000). Transformation of rice with the Arabidopsis floral regulator LEAFY causes early heading. Transgenic Research, 9, 223-227. https://doi.org/10.1023/A:1008992719010

Heidari, H. (2012). Effect of irrigation by contaminated water with cloth detergent on plant growth and seed germination traits of maize (Zea mays). Life Science Journal, 9, 1587-1590. http://www.lifesciencesite.com/Isj/life0 904/241_11901life0904_1587_1590.pdf

Hickman, J. C. (1975). Environmental unpredictability and plastic energy allocation strategies in the annual Polygonum cascadense (Polygonaceae). Journal of Ecology, 63, 689-701. https://doi.org/10.2307/2258745

Hooftman, D. A. P., Hartman, Y., \& Oostermeijer, J. G. B. (2009). Existence of vigorous lineages of crop-wild hybrids in lettuce under field conditions. Environmenta Biosafety Research, 8, 203-217. https://doi.org/10.1051/ebr/2010001

Horton, M., \& Lacey, E. P. (1994). Carbon integration in Plantago aristata (Plantaginaceae): The reproductive effects of defoliation. American Journal of Botany, 81, 278-286. https://doi.org/10.2307/2445453
Huang, S. C., \& Hong, T. S. (1983). Effects of planting density on the growth of Job's tears (Coix lacryma-jobi L.). Bulletin of Taichung District Agricultural Improvement Station, 7, 45-52. https://www.tdais.gov.tw/ws.php?id=515

Irzykowska, L., \& Wolko, B. (2004). Interval mapping of QTLs controlling yieldrelated traits and seed protein content in Pisum sativum. Journal of Applied Genetics, 45, 297-306. http://jag.igr.poznan.pl/2004-Volume-45/3/abstr acts/211.html

Isemura, T., Kaga, A., Konishi, S., Ando, T., Tomooka, N., Han, O. K., \& Vaughan, D. A. (2007). Genome dissection of traits related to domestication in azuki bean (Vigna angularis) and comparison with other warm-season legumes. Annals of Botany, 100, 1053-1071. https://doi.org/10.1093/aob/mcm155

Jackson, R. B., Sala, O. E., Field, C. B., \& Mooney, H. A. (1994). $\mathrm{CO}_{2}$ alters water use, carbon gain, and yield for the dominant species in a natural grassland. Oecologia, 98, 257-262. https://doi.org/10.1007/BF00324212

Jin, Y., He, J., Turner, N. C., Du, Y. L., \& Li, F. M. (2019). Water-conserving and biomass-allocation traits are associated with higher yields in modern cultivars compared to landraces of soybean [Glycine max (L.) Merr.] in rainfed waterlimited environments. Environmental and Experimental Botany, 168, 103883. https://doi.org/10.1016/j.envexpbot.2019.103883

Khan, S., Kozgar, M. I., Goyal, S., \& Wani, M. R. (2011). Induction of morphological mutants in mungbean (Vigna radiata (L.) Wilczek) through chemical mutagens. The Nucleus, 48, 243-247. http://thenucleuspak.org.pk/index.php/Nucleus/ article/view/839

Koptur, S., Smith, C. L., \& Lawton, J. H. (1996). Effects of artificial defoliation on reproductive allocation in the common vetch, Vicia sativa (Fabaceae: Papilionoideae). American Journal of Botany, 83, 886-889. https://doi. org/10.1002/j.1537-2197.1996.tb12780.x

Lafond, G. P. (1994). Effects of row spacing, seeding rate and nitrogen on yield of barley and wheat under zero-till management. Canadian Journal of Plant Science, 74, 703-711. https://doi.org/10.4141/cjps94-127

Lehtilä, K., \& Strauss, S. Y. (1999). Effects of foliar herbivory on male and female reproductive traits of wild radish, Raphanus raphanistrum. Ecology, 80, 116-124. https://doi.org/10.1890/0012-9658(1999)080[0116:EOFHOM]2.0.CO;2

Leishman, M. R., Sanbrooke, K. J., \& Woodfin, R. M. (1999). The effects of elevated $\mathrm{CO}_{2}$ and light environment on growth and reproductive performance of four annual species. New Phytologist, 144, 455-462. https://doi org/10.1046/j.1469-8137.1999.00544.x

Ludwig, F., Rosenthal, D. M., Johnston, J. A., Kane, N., Gross, B. L., Lexer, C., Dudley, S. A., Rieseberg, L. H., \& Donovan, L. A. (2004). Selection on leaf ecophysiological traits in a desert hybrid Helianthus species and early-generation hybrids. Evolution, 58, 2682-2692. https://doi.org/10.1554/04-423

Lule, D., Tesfaye, K., Fetene, M., \& De Villiers, S. (2012). Inheritance and association of quantitative traits in finger millet (Eleusine coracana Subsp. coracana) landraces collected from eastern and south eastern Africa. International Journal of Genetics, 2, 12-21. http://oar.icrisat.org/7073/

Luo, L. J., Li, Z. K., Mei, H. W., Shu, Q. Y., Tabien, R., Zhong, D. B., Ying, C. S., Stansel, J. W., Khush, G. S., \& Paterson, A. H. (2001). Overdominant epistatic loci are the primary genetic basis of inbreeding depression and heterosis in rice. II. Grain yield components. Genetics, 158, 1755-1771. https://www.genetics.org/ content/158/4/1755

Mabry, C. M., \& Wayne, P. W. (1997). Defoliation of the annual herb Abutilon the ophrasti: Mechanisms underlying reproductive compensation. Oecologia, 111, 225-232. https://doi.org/10.1007/s004420050229

Manyasa, E. O. (2007). Genetic diversity in Tanzanian pigeonpea [Cajanus cajan (L.) Millsp.] landraces (Doctoral dissertation) University of NAIROBI. http://erepo sitory.uonbi.ac.ke/handle/11295/20172

Marshall, D. L., Abrahamson, N. J., Avritt, J. J., Hall, P. M., Medeiros, J. S., Reynolds, J., Reynolds, J., Shaner, M. G. M., Simpson, H. L., Trafton, A. N., Tyler, A. P., \& Walsh, S. (2005). Differences in plastic responses to defoliation due to variation in the timing of treatments for two species of Sesbania (Fabaceae). Annals of Botany, 95, 1049-1058. https://doi.org/10.1093/aob/mci116

Matthies, D. (1990). Plasticity of reproductive components at different stages of development in the annual plant Thlaspi arvense L. Oecologia, 83, 105-116. https://doi.org/10.1007/BF00324641

McKone, M. J., \& Tonkyn, D. W. (1986). Intrapopulation gender variation in common ragweed (Asteraceae: Ambrosia artemisiifolia L.), a monoecious, annual herb. Oecologia, 70, 63-67. https://doi.org/10.1007/BF00377111

Mehrvarz, S., \& Chaichi, M. R. (2008). Effect of phosphate solubilizing microorganisms and phosphorus chemical fertilizer on forage and grain quality of barley (Hordeum vulgare L.). American-Eurasian Journal of Agricultural and Environmental Science, 3, 822-828. https://www.idosi.org/aejaes/jaes3(6)/10.pdf 
Mensah, J. K., \& Ihenyen, J. (2009). Effects of salinity on germination, seedling establishment and yield of three genotypes of mung bean (Vigna mungo L. Hepper) in Edo State, Nigeria. Nigerian Annals of Natural Science, 8, 17-24.

Mensah, J. K., Obadoni, B. O., Eruotor, P. G., \& Onome-Irieguna, F. (2006). Simulated flooding and drought effects on germination, growth, and yield parameters of sesame (Sesamum indicum L.). African Journal of Biotechnology, 5, 1249-1253. https://www.ajol.info/index.php/ajb/article/view/43092

Mensah, J. K., \& Tope, O. R. (2007). Performance of mung beans (Vigna mungo L. Hepper) grown in mid-west Nigeria. American-Eurasian Journal of Agricultural and Environmental Science, 2, 696-701.

Milczak, M., Pedzinski, M., Mnichowska, H., Szwed-Urbas, K., \& Rybinski, W. (2001). Creative breeding of grasspea (Lathyrus sativus L.) in Poland. Lathyrus Lathyrism Newsletter, 2, 85-88. https://www.clima.uwa.edu.au/_data/assets/ pdf_file/0012/919749/Rybinski.pdf

Mohammadi, A. A., Saeidi, G., \& Arzani, A. (2010). Genetic analysis of some agronomic traits in flax (Linum usitatissimum L.). Australian Journal of Crop Science, 4 , 343-352. http://www.cropj.com/mohammadi_3_5_2010_343_352.pdf

Morishima, H., Sano, Y., \& Oka, H. I. (1984). Differentiation of perennial and annual types due to habitat conditions in the wild rice Oryza perennis. Plant Systematics and Evolution, 144, 119-135. https://doi.org/10.1007/BF00986670

Mozumder, S. N., Salim, M., Islam, N., Nazrul, M. I., \& Zaman, M. M. (2003). Effect of Bradyrhizobium inoculum at different nitrogen levels on summer mungbean. Asian Journal of Plant Sciences, 2, 817-822. https://doi.org/10.3923/ ajps.2003.817.822

Muir, J. P., Reed, R. L., \& Malinowski, D. P. (2005). Impact of defoliation on herbage and seed production of Strophostyles helvula and S. leiosperma. Native Plants Journal, 6, 123-130. https://doi.org/10.2979/NPJ.2005.6.2.123

Mulungu, L. S., Tarimo, A. J., Reuben, S. O., Lema, D. N., Makundi, R. H., \& Massawe, A. W. (2006). Effect of seedbed type on yield and yield components of common bean (Phaseolus vulgaris L.) commercial cultivars. Journal of Agronomy, 5, 583588. https://doi.org/10.3923/ja.2006.583.588

Mutikainen, P., Walls, M., \& Ojala, A. (1993). Effects of simulated herbivory on tillering and reproduction in an annual ryegrass, Lolium remotum. Oecologia, 95 54-60. https://doi.org/10.1007/BF00649506

Nabipour, M., Meskarbashee, M., \& Yousefpour, H. (2007). The effect of water deficit on yield and yield components of safflower (Carthamus tinctorius L.). Pakistan Journal of Biological Sciences, 10, 421-426. https://doi.org/10.3923/ pjbs.2007.421.426

Nawaz, N., Razzaq, A., Ali, Z., Sarwar, G., \& Yousaf, M. (2004). Performance of different oat (Avena sativa L.) varieties under the agro-climatic conditions of Bahawalpur-Pakistan. International Journal of Agriculture and Biology, 6, 624626. https://www.fspublishers.org/Issue.php?no_download=published_paper s/3089_.pdf\&issue_id=2480

Nderitu, J., Nyamasyo, G., Kasina, M., \& Oronje, M. L. (2008). Diversity of sunflower pollinators and their effect on seed yield in Makueni District, Eastern Kenya. Spanish Journal of Agricultural Research, 6, 271-278. https://doi.org/10.5424/ SJAR/2008062-318

Newman, D., \& Tallmon, D. A. (2001). Experimental evidence for beneficial fitness effects of gene flow in recently isolated populations. Conservation Biology, 15 1054-1063. https://doi.org/10.1046/J.1523-1739.2001.0150041054.X

Pandini, F., Vello, N. A., \& Lopes, Â. C. D. A. (2002). Heterosis in soybeans for seed yield components and associated traits. Brazilian Archives of Biology and Technology, 45, 401-412. https://doi.org/10.1590/S1516-8913200200 0600001

Parvez, M. A., Muhammad, F., \& Ahmad, M. (2000). Effect of depodding on the growth and yield of peas (Pisum sativum L.). Pakistan Journal of Biological Sciences, 3, 1281-1282. https://doi.org/10.3923/pjbs.2000.1281.1282

Pekşen, E., \& Artık, C. (2004). Comparison of some cowpea (Vigna unguiculata L. Walp) genotypes from Turkey for seed yield and yield related characters. Journal of Agronomy, 3, 137-140. https://doi.org/10.3923/ja.2004.137.140

Phanacharoensawad, R. (2009). The potential for growing teff (Eragrostis tef [Zucc.] Trotter) in Thailand. Asian Journal of Food and Agro-Industry, 2, S125-S131. http://www.ajofai.info/Abstract/The\%20potential\%20for\%20growing\%20 tef\%20(eragrostis\%20tef\%20(zucc.)\%20trotter)\%20in\%20thailand.pdf

Pilson, D., \& Decker, K. L. (2002). Compensation for herbivory in wild sunflower: Response to simulated damage by the head-clipping weevil. Ecology, 83, 3097 3107. https://doi.org/10.1890/0012-9658(2002)083[3097:CFHIWS]2.0.CO;2

Pimratch, S., Jogloy, S., Toomsan, B., Jaisil, P., Kesmala, T., \& Patanothai, A. (2004). Heritability and correlation for nitrogen fixation and agronomic traits of peanut (Arachis hypogaea L.). Songklanakarin Journal of Science and Technology, 26, 305315. https://rdo.psu.ac.th/sjstweb/journal/26-3/02traitofpeanut.pdf
Pospišil, A., Pospišil, M., Varga, B., \& Svečnjak, Z. (2006). Grain yield and protein concentration of two amaranth species (Amaranthus spp.) as influenced by the nitrogen fertilization. European Journal of Agronomy, 25, 250-253. https://doi. org/10.1016/j.eja.2006.06.001

Preece, C., Livarda, A., Christin, P.-A., Wallace, M., Martin, G., Charles, M., Jones, G., Rees, M., \& Osborne, C. P. (2017). How did the domestication of Fertile Crescent grain crops increase their yields? Functional Ecology, 31, 387-397. https://doi.org/10.1111/nph.13353

Primack, R. B., \& Antonovics, J. (1981). Experimental ecological genetics in Plantago. V. Components of seed yield in the ribwort plantain Plantago lanceolata L. Evolution, 35, 1069-1079. https://doi.org/10.1111/j.1558-5646.1981.tb049 $75 . x$

Radchuk, V., Radchuk, R., Pirko, Y., Vankova, R., Gaudinova, A., Korkhovoy, V., Yemets, A., Weber, H., Weschke, W., \& Blume, Y. B. (2012). A somaclonal line SE7 of finger millet (Eleusine coracana) exhibits modified cytokinin homeostasis and increased grain yield. Journal of Experimental Botany, 63, 5497-5506. https://doi.org/10.1093/jxb/ers200

Rao, S., \& Rao, D. (1982). Studies on the effect of X-irradiation on Cyamopsis tetragonoloba (L.) Taub. Proceedings of the Indian National Science Academy, Part B, 48, 410-415. https://insa.nic.in/writereaddata/UpLoadedFiles/PINSA/ Vol48B 1982 3_Art14.pdf

Rao, N. K., \& Shahid, M. (2011). Potential of cowpea (Vigna unguiculata (L.) Walp.) and guar [Cyamopsis tetragonoloba (L.)] as alternative forage legumes for the United Arab Emirates. Emirates Journal of Food and Agriculture, 23, 147-156. https://doi.org/10.9755/ejfa.v23i2.6349

Renno, J. F., \& Winkel, T. (1996). Phenology and reproductive effort of cultivated and wild forms of Pennisetum glaucum under experimental conditions in the Sahel: Implications for the maintenance of polymorphism in the species. Canadian Journal of Botany, 74, 959-964. https://doi.org/10.1139/b96-119

Rudgers, J. A., \& Hoeksema, J. D. (2003). Inter-annual variation in above-and belowground herbivory on a native, annual legume. Plant Ecology, 169, 105. https:// doi.org/10.1023/A:1026221602968

Ruiz, R. A., \& Bertero, H. D. (2008). Light interception and radiation use efficiency in temperate quinoa (Chenopodium quinoa Willd.) cultivars. European Journal of Agronomy, 29, 144-152. https://doi.org/10.1016/j.eja.2008.05.003

Ruiz de Clavijo, E. (2002). Role of within-individual variation in capitulum size and achene mass in the adaptation of the annual Centaurea eriophora to varying water supply in a Mediterranean environment. Annals of Botany, 90, 279-286. https://doi.org/10.1093/aob/mcf188

Rybiński, W. (2003). Mutagenesis as a tool for improvement of traits in grasspea (Lathyrus sativus L.). Lathyrus Lathyrism Newsletter, 3, 27-31. https://www. clima.uwa.edu.au/_data/assets/pdf_file/0011/919802/Rybinski.pdf

Sabbahi, R., DeOliveira, D., \& Marceau, J. (2005). Influence of honey bee (Hymenoptera: Apidae) density on the production of canola (Crucifera: Brassicacae). Journal of Economic Entomology, 98, 367-372. https://doi. org/10.1093/jee/98.2.367

Saleem, M. F., Ma, B. L., Malik, M. A., Cheema, M. A., \& Wahid, M. A. (2008). Yield and quality response of autumn-planted sunflower (Helianthus annuus L.) to sowing dates and planting patterns. Canadian Journal of Plant Science, 88, 101109. https://doi.org/10.4141/CJPS07052

Sana, M., Ali, A., Malik, M. A., Saleem, M. F., \& Rafiq, M. (2003). Comparative yield potential and oil contents of different canola cultivars (Brassica napus L.). Journal of Agronomy, 2, 1-7. https://doi.org/10.3923/ja.2003.1.7

Seghatoleslami, M. J., Kafi, M., \& Majidi, E. (2008a). Effect of deficit irrigation on yield, WUE and some morphological and phenological traits of three millet species. Pakistan Journal of Botany, 40, 1555-1560. http://www.pakbs.org/pjbot/ PDFs/40(4)/PJB40(4)1555.pdf

Seghatoleslami, M. J., Kafi, M., \& Majidi, E. (2008b). Effect of drought stress at different growth stages on yield and water use efficiency of five proso millet (Panicum miliaceum L.) genotypes. Pakistan Journal of Botany, 40, 1427-1432. http://www.pakbs.org/pjbot/PDFs/40\%284\%29/PJB40\%284\% 291427.pdf

Shamsi, K., Kobraee, S., \& Rasekhi, B. (2011). The effects of different planting densities on seed yield and quantitative traits of rainfed chickpea (Cicer arietinum L.) varieties. African Journal of Agricultural Research, 6, 655-659. https://doi. org/10.5897/AJAR10.566

Shrestha, R., Siddique, K. H. M., Turner, N. C., Turner, D. W., \& Berger, J. D. (2005). Growth and seed yield of lentil (Lens culinaris Medikus) genotypes of West Asian and South Asian origin and crossbreds between the two under rainfed conditions in Nepal. Australian Journal of Agricultural Research, 56, 971-981. https://doi.org/10.1071/AR05050 
Sims, L. T. (2011). Light, nitrogen and phosphorus effects on growth, allocation of biomass and nutrients, reproduction and fitness in wild rice (Zizania palustris L.). Botany-Botanique, 90, 876-883. https://doi.org/10.1139/b2012-057

Sliesaravièius, A., Petraitytë, N., \& Dastikaitë, A. (2005). A study of phenotypical diversity in wild narrow-leaved vetch (V. angustifolia L.). Biologija, 2005, 31-35. http://mokslozurnalai.Imaleidykla.lt/publ/1392-0146/2005/3/ Bio_031_035NN.pdf

Smidansky, E. D., Clancy, M., Meyer, F. D., Lanning, S. P., Blake, N. K., Talbert, L. E., \& Giroux, M. J. (2002). Enhanced ADP-glucose pyrophosphorylase activity in wheat endosperm increases seed yield. Proceedings of the National Academy of Sciences of the United States of America, 99, 1724-1729. https://doi. org/10.1073/pnas.022635299

Snow, A. A., Moran-Palma, P., Rieseberg, L. H., Wszelaki, A., \& Seiler, G. J. (1998). Fecundity, phenology, and seed dormancy of F1 wild-crop hybrids in sunflower (Helianthus annuus, Asteraceae). American Journal of Botany, 85, 794-801. https://doi.org/10.2307/2446414

Togay, Y., Togay, N., \& Dogan, Y. (2008). Research on the effect of phosphorus and molybdenum applications on the yield and yield parameters in lentil (Lens culinaris Medic.). African Journal of Biotechnology, 7, 1256-1260. https://www.ajol. info/index.php/ajb/article/view/58658

Tonçer, Ö., \& Kizil, S. (2004). Effect of seed rate on agronomic and technologic characters of Nigella sativa L. International Journal of Agriculture and Biology, 6, 529-532.

Trenbath, B. R., \& Harper, J. L. (1973). Neighbour effects in the genus Avena. I. Comparison of crop species. Journal of Applied Ecology, 10, 379-400. https:// doi.org/10.2307/2402288

van Oosterom, E. J., Bidinger, F. R., \& Weltzien, E. R. (2003). A yield architecture framework to explain adaptation of pearl millet to environmental stress. Field Crops Research, 80, 33-56. https://doi.org/10.1016/S0378-4290(02)00153-3

Vara Prasad, P., Boote, K. J., Allen, L. H. Jr, \& Thomas, J. M. (2002). Effects of elevated temperature and carbon dioxide on seed-set and yield of kidney bean (Phaseolus vulgaris L.). Global Change Biology, 8, 710-721. https://doi. org/10.1046/j.1365-2486.2002.00508.x

Verhoeven, K. J., Biere, A., Nevo, E., \& Van Damme, J. M. (2004). Differential selection of growth rate-related traits in wild barley, Hordeum spontaneum, in contrasting greenhouse nutrient environments. Journal of Evolutionary Biology, 17, 184-196. https://doi.org/10.1046/j.1420-9101.2003.00636.x

Verhoeven, K. J., Vanhala, T. K., Biere, A., Nevo, E., \& Damme, J. M. V. (2004). The genetic basis of adaptive population differentiation: A quantitative trait locus analysis of fitness traits in two wild barley populations from contrasting habitats. Evolution, 58, 270-283. https://doi.org/10.1554/03-033

Volis, S. (2007). Correlated patterns of variation in phenology and seed production in populations of two annual grasses along an aridity gradient. Evolutionary Ecology, 21, 381-393. https://doi.org/10.1007/s10682-006-9108-x

Vorasoot, N., Songsri, P., Akkasaeng, C., Jogloy, S., \& Patanothai, A. (2003). Effect of water stress on yield and agronomic characters of peanut (Arachis hypogaea L.). Songklanakarin Journal of Science and Technology, 25, 283-288. https://rdo. psu.ac.th/sjstweb/journal/25-3/01waterstresspeanut.pdf
Wests, D. W., \& Francois, L. E. (1982). Effects of salinity on germination, growth and yield of cowpea. Irrigation Science, 3, 169-175. https://doi.org/10.1007/ BF00446005

Wu, B., Liu, H., Zhao, B., Tong, X., Zhao, Q., \& Wan, P. (2010). Colchicine-induced trait variations in azuki bean (Vigna angularis). Legume Genomics and Genetics, 1 , 1-8. https://doi.org/10.5376/lgg.2010.01.0007

Wu, H., Sun, M., Yue, S., Sun, H., Cai, Y., Huang, R., Brenner, D., \& Corke, H. (2000). Field evaluation of an Amaranthus genetic resource collection in China. Genetic Resources and Crop Evolution, 47, 43-53. https://doi.org/10.1023/A:10087 71103826

Yadav, R. S., Hash, C. T., Bidinger, F. R., Cavan, G. P., \& Howarth, C. J. (2002) Quantitative trait loci associated with traits determining grain and stover yield in pearl millet under terminal drought-stress conditions. Theoretical and Applied Genetics, 104, 67-83. https://doi.org/10.1007/s001220200008

Yilmaz, N. (2003). The effects of seed rate on yield and yield components of soybean (Glycine max L. Merill). Pakistan Journal of Biological Sciences, 6, 373-376. https://doi.org/10.3923/pjbs.2003.373.376

Zając, T., Oleksy, A., Stokłosa, A., \& Klimek-Kopyra, A. (2011). Comparison of morphological traits, productivity and canopy architecture of winter oilseed rape (Brassica napus L.) and white mustard (Sinapis alba L.). Journal of Applied Botany and Food Quality, 84, 183-191. https://ojs.openagrar.de/index.php/JABFQ/ article/view/1829

Zhang, S., Zhao, C., \& Lamb, E. G. (2011). Cotyledon damage affects seed number through final plant size in the annual grassland species Medicago lupulina. Annals of Botany, 107, 437-442. https://doi.org/10.1093/aob/mcq259

Zou, L., Stout, M. J., \& Dunand, R. T. (2004). The effects of feeding by the rice water weevil, Lissorhoptrus oryzophilus Kuschel, on the growth and yield components of rice, Oryza sativa. Agricultural and Forest Entomology, 6, 47-54. https://doi. org/10.1111/j.1461-9555.2004.00203.x

\section{SUPPORTING INFORMATION}

Additional supporting information may be found online in the Supporting Information section.

How to cite this article: Garibaldi LA, Aizen MA, Sáez A, Gleiser G, Strelin MM, Harder LD. The influences of progenitor filtering, domestication selection and the boundaries of nature on the domestication of grain crops. Funct Ecol. 2021;00:1-14. https://doi.org/10.1111/13652435.13819 